\title{
BEZPOŚREDNIE KONTENEROWE SERWISY DALEKO- WSCHODNIE Z GDAŃSKA SZANSĄ DLA ROZWOJU EKSPORTU POLSKICH PRODUKTÓW SPOŻYWCZYCH
}

\begin{abstract}
Streszczenie
Artykuł porusza probemlatykę żeglugi kontenerowej, chłodniczego łańcucha dostaw oraz polsko-azjatyckiej wymiany handlowej.

Celem opracowania jest wskazanie szans dla eksportu polskich produktów spożywczych przy wykorzystaniu żeglugi oceanicznej z Gdańska. W artykule dokonano analizy serwisów żeglugowych z Polski w kierunkach Dalekiego Wschodu oraz polskiego eksportu wybranych towarów spożywczych. Zdefiniowano podstawowe pojęcia i procesy transportu morskiego z nastawieniem na przewozy ładunków chłodzonych. Wskazano potrzebę prac badawczo-rozwojowych $\mathrm{w}$ celu usprawnienia eksportu towarów spożywczych z Polski.

Słowa kluczowe: eksport, alianse armatorskie, kontenery chłodnicze, serwisy żeglugi kontenerowej, eksport żywności.
\end{abstract}

\section{Wstęp}

Duże zmiany organizacyjne $\mathrm{w}$ żegludze kontenerowej zaszły na początku drugiego kwartału 2017 roku, kiedy dotychczasowe alianse (G6 Alliance, Ocean Three Alliance, CKYHE Alliance) zakończyły działalność, a w zamian powstały nowe sojusze, stworzone przez głównych graczy wśród globalnych operatorów żeglugi kontenerowej. Być może w tych zmienionych układach coopetition (konkurencji i współpracy) będzie więcej owocnej współpracy niż zbyt ostrej konkurencji, która przynosiła armatorom ogromne straty finansowe grożące bankructwami.

Obecnie funkcjonują trzy globalne strategiczne alianse (Ocean Alliance, The Alliance, 2M Alliance), które obsługują linie żeglugowe na głównych szlakach handlowych pomiędzy Azją a Europą i Ameryką Północną oraz linie transaltantyczne między Europą a Ameryką Północną. Dla dwóch z sojuszy (Ocean Allian- 
ce i 2M Alliance) Gdańsk stał się jednym z kluczowych portów w Europie Północnej, obsługując dwa bezpośrednie serwisy na szlaku Azja-Europa-Azja. Można uznać to za wielkie zwycięstwo Gdańska wśród portów w basenie Morza Bałtyckiego (World Maritime News, 2017), ponieważ współpraca z największymi aliansami wpływa na rozwój polskiego portu oraz umacnia jego pozycję jako portu bazowego linii żeglugowych i hubu stymulującego rozwój tranzytu morskiego (PortalMorski.pl, 2009).

Dzięki możliwości korzystania z bezpośrednich serwisów żeglugowych polscy producenci mają szansę na ekspansję eksportową na rynku chińskim oraz innych rynkach Azji Południowo-Wschodniej. Celem niniejszego opracowania jest wskazanie szans dla eksportu polskich towarów spożywczych na rynki azjatyckie dzięki bezpośrednim połączeniom żeglugowym. Struktura artykułu podporządkowana jest realizacji tego celu, składa się bowiem ze wstępu, trzech części merytorycznych i podsumowania. W pierwszej części pokazano zmiany w globalnej i lokalnej żegludze kontenerowej. $\mathrm{W}$ drugiej części przeanalizowano polsko-chińską wymianę handlową ze wskazaniem szans na rozwój. W części trzeciej dokonano krytycznej analizy eksportu wybranych towarów spożywczych. Najważniejsze wnioski z przeprowadzonej analizy wskazano w podsumowaniu.

\section{Serwisy żeglugi kontenerowej w porcie w Gdańsku}

\subsection{Globalne sojusze armatorskie}

Obecnie w największych aliansach żeglugi kontenerowej uczestniczy 12 armatorów, którzy równocześnie są największymi graczami na światowym rynku tej żeglugi. Ich miejsce w rankigu TOP100 według Alphaliner oraz wielkość floty zestawiono w tabeli 1.

Tabela 1. Flota eksploatowana przez członków globalnych aliansów kontenerowych w 2018 roku

\begin{tabular}{|c|c|c|c|c|c|c|c|}
\hline \multirow{2}{*}{$\begin{array}{l}\text { Alianse i ich } \\
\text { członkowie }\end{array}$} & \multirow{2}{*}{$\begin{array}{c}\text { Ranking } \\
\text { TOP100 }\end{array}$} & \multicolumn{2}{|c|}{ Oferowana pojemność } & \multicolumn{2}{|c|}{ Flota własna } & \multicolumn{2}{|c|}{ Flota czarterowana } \\
\hline & & TEU & $\begin{array}{c}\text { Statki } \\
\text { [szt.] }\end{array}$ & TEU & $\begin{array}{c}\text { Statki } \\
\text { [szt.] }\end{array}$ & TEU & Statki [szt.] \\
\hline $\begin{array}{c}\text { 2M Alliance } \\
+ \text { HMM }\end{array}$ & & 7681075 & 1301 & 3506009 & 521 & 4175066 & 780 \\
\hline $\begin{array}{l}\text { MAERSK } \\
\text { LINE }\end{array}$ & 1. & 4020205 & 713 & 2283942 & 312 & 1736263 & 401 \\
\hline MSC & 2. & 3246580 & 515 & 1092628 & 195 & 2153952 & 320 \\
\hline HYUNDAI* & 11. & 414290 & 73 & 129439 & 14 & 284851 & 59 \\
\hline $\begin{array}{c}\text { OCEAN } \\
\text { ALLIANCE }\end{array}$ & & 6642735 & 1194 & 2858789 & 400 & 3783946 & 794 \\
\hline cosco & 3. & 2820118 & 479 & 1285891 & 155 & 1534227 & 324 \\
\hline
\end{tabular}




\begin{tabular}{|c|c|c|c|c|c|c|c|}
\hline $\begin{array}{l}\text { CMA CGM } \\
\text { EVERGREEN }\end{array}$ & $\begin{array}{l}4 . \\
7 .\end{array}$ & $\begin{array}{l}2662605 \\
1160012\end{array}$ & $\begin{array}{l}512 \\
203 \\
\end{array}$ & $\begin{array}{l}993306 \\
579592 \\
\end{array}$ & $\begin{array}{l}130 \\
115 \\
\end{array}$ & $\begin{array}{c}1669299 \\
580420 \\
\end{array}$ & $\begin{array}{c}382 \\
88 \\
\end{array}$ \\
\hline $\begin{array}{c}\text { THE } \\
\text { ALLIANCE }\end{array}$ & & 3772219 & 549 & 1815448 & 232 & 1956771 & 317 \\
\hline $\begin{array}{l}\text { HAPAG } \\
\text { LLOYD }\end{array}$ & 5. & 1583626 & 220 & 1047266 & 112 & 536360 & 108 \\
\hline ONE & 6. & 1540162 & 226 & 584599 & 80 & 955563 & 146 \\
\hline $\begin{array}{l}\text { YANG } \\
\text { MING }\end{array}$ & 8. & 648431 & 103 & 183583 & 40 & 464848 & 63 \\
\hline OGÓŁEM & $X$ & 18096029 & 3044 & 8180246 & 1153 & 9915783 & 1891 \\
\hline
\end{tabular}

* Armator HMM, broniąc się przed bankructwem, nawiązał strategiczną współpracę z partnerami aliansu 2M Maersk Line i MSC w ramach serwisów na szlakach Azja - Europa i Azja - USA.

Źródło: Opracowanie własne na podstawie www.alphaliner.com, 30 sierpnia 2018

2M rozpoczął swoją działalność w styczniu 2015 r. w oparciu o dziesięcioletnią umowę VSA, czyli vessel sharing agreements (umówę o podziale przestrzeni ładunkowej statków) pomiędzy MAERSK oraz MSC. W kwietniu 2017 r. do współpracy z 2M dołączył południowokoreański armator Hyundai na podstawie umowy kupna i sprzedaży miejsc pod kontenery na statkach sojuszu na okres trzech lat. Armatorzy MAERSK i MSC, rozpoczynając wspólne serwisy, dzielili flotę 185 statków o pojemności 2,1 miliona TEU na 21 pętlach (World Maritime News, 2015). Z czasem, między innymi poprzez wprowadzanie statków o większej pojemności czy przejęcia np. armatora Hamburg Süd przez grupę MAERSK, liczby te uległy zmianie. Dla trzech największy sojuszy w 2018 roku liczba statków, pojemność floty globalnych aliansów kontenerowych oraz liczbę serwisów i połączeń między portami zestawiono w tabeli 2.

Tabela 2. Liczba statków, pojemność floty, liczba serwisów i połączeń między portami globalnych sojuszy kontenerowych w 2018 roku

\begin{tabular}{|l|l|c|c|}
\hline Sojusz & 2M & Ocean Alliance & THE Alliance \\
\hline Liczba statków & 223 & 331 & 241 \\
\hline Pojemność w TEU & $2,4 \mathrm{mln}$ & $3,5 \mathrm{mln}$ & $3,3 \mathrm{mln}$ \\
\hline $\begin{array}{l}\text { Liczba cotygodnio- } \\
\text { wych serwisów }\end{array}$ & 25 & 40 & 32 \\
\hline Liczba par portów & 1327 & 1571 & 1152 \\
\hline
\end{tabular}

Źródło: Opracowanie własne na podstawie www.xeneta.com, 15 września 2018

Należy również zaznaczyć, że w działalności przedsiębiorstw armatorskich wyrazem tendencji integracyjnych jest nie tylko tworzenie strategicznych sojuszy, ale również fala przejęć i fuzji. W grudniu $2015 \mathrm{r}$. francuski armator CMA CGM zakupił od singapurskiej spółki Temasek grupę NOL (Neptune Orient Lines), 
właściciela dwunastego największego armatora na świecie o nazwie APL. W lutym 2016 roku chińscy armatorzy COSCO oraz China Shipping połączyli się $\mathrm{w}$ jedną korporację o nazwie COSCO Shipping Lines Co. Ltd. Poważnym wstrząsem na rynku żeglugi kontenerowej był upadek, w połowie 2016 roku, jednego z największych armatorów - koreańskiego Hanjin Shipping. W tym samym czasie niemiecki armator Hapag Lloyd zawarł porozumienie połączenia się z arabskimi partnerami, właścicielami armatora UASC (United Arab Shipping Company), zachowując nazwę Hapag Lloyd. W listopadzie 2016 roku japońscy armatorzy MOL, NYK Line oraz K Line ogłosili plan utworzenia jednego, wspólnego armatora o nazwie ONE (Ocean Network Express). W grudniu 2016 roku duński armator MAERSK Line wyraził intencję przejęcia niemieckiego operatora żeglugowego Hamburg Süd - transakcja została zakończona rok później, w listopadzie 2017 roku, natomiast w czerwcu 2018 r. COSCO Shipping Holdings potwierdził otrzymanie niezbędnych pozwoleń na przejęcie siódmego największego operatora żeglugowego Orient Overseas Container Lines (OOCL).

\subsection{Sojusze armatorskie w Polsce na kierunku Europa-Azja}

2M Alliance oraz Ocean Alliance oferują bezpośrednie zawinięcia do Gdańska w ramach serwisów: AE10 oraz FAL5. Rotacja serwisów na kierunku EuropaAzja jest następująca: dla AE10 Gdańsk, Bremenhaven, Felixstowe, Tanjung Pelepas, Szanghai, Dalian, Busan, Kwangyang (luty 2018 r.); dla FAL5 Rotterdam, Gdańsk, Wilhelmshaven, Felixstowe, Singapur, Yantian, Szanghaj, Ningbo, Xiamen (sierpień 2018 r.). Bezpośrednie zawinięcia do Gdańska gwarantują szybszy czas tranzytu (w żegludze liczony od wyjścia z portu załadunku do wyładunku kontenera $\mathrm{w}$ porcie destynacji) oraz dostaw, ponieważ unika się oczekiwania na statki oceaniczne i operacji przeładunku w portach hubach w Europie PółnocnoZachodniej (np. w porcie w Hamburgu). Ma to szczególne znaczenie przy wysyłkach towarów chłodzonych i mrożonych do największych miast w Chinach, obsługiwanych przez najważniejsze porty kontenerowe, takie jak Szanghaj (36 516 000 TEU), Ningbo (20 636000 TEU) czy Shenzen (24 142000 TEU) (Central Inteligence Agency United States of America, 2017). W tabeli 2 zamieszczono porównanie czasu tranzytu (TT - transit time) dla serwisów bezpośrednich oraz serwisu The Alliance z Gdyni z przeładunkiem kontenerów w porcie Hamburg. Serwisy bezpośrednie "wygrywają" czasem podróży od około 2 dni (Xiamen) do 20 dni (Szanghaj). Serwisy bezpośrednie oferują szybsze połączenia, w szczególności do portów w północnej części Chin. 
Tabela 2. Czas tranzytu do portów bazowych w serwisach 2M Alliance i Ocean Alliance z Gdańska oraz The Alliance z Gdyni w 2018 roku

\begin{tabular}{|c|c|c|c|c|c|}
\hline $\begin{array}{c}\text { 2M Alliance } \\
\text { Porty Bazowe }\end{array}$ & $\begin{array}{c}\text { TT z } \\
\text { GDAŃSKA } \\
\text { [dni] }\end{array}$ & $\begin{array}{c}\text { OCEAN Allian- } \\
\text { ce Porty Bazowe }\end{array}$ & $\begin{array}{c}\text { TT z } \\
\text { GDANSKA } \\
\text { [dni] }\end{array}$ & $\begin{array}{c}\text { The Alliance } \\
\text { Porty Bazowe } \\
\text { via Hamburg }\end{array}$ & $\begin{array}{c}\text { TT z } \\
\text { GDYNI } \\
\text { [dni] }\end{array}$ \\
\hline TANJUNG & 28 & SINGAPUR & 30 & SINGAPUR & 34 \\
PELEPAS & 35 & YANTIAN & 35 & YANTIAN & 43 \\
SZANGHAJ & 37 & SZANGHAJ & 38 & SZANGHAJ & 54 \\
DALIAN & 40 & NINGBO & 40 & NINGBO & 52 \\
BUSAN & 41 & XIAMEN & 43 & XIAMEN & 45 \\
KWANGYANG & 44 & & DALIAN & 50 \\
NINGBO & & & &
\end{tabular}

Źródło: opracowanie własne na podstawie stron internetowych armatorów: www.maerskline.com, www.cma-cgm.com, www.hapag-lloyd.com, 15 lutego 2018

Poza czasem przewozu ładunku pomiędzy portami załadunku i wyładunku, ważnymi czynnikami wpływającym na polski eksport do Azji jest regularność serwisów oraz dostęp do miejsca na statkach wypływających z Gdańska. Serwisy bezpośrednie zorganizowane są $\mathrm{w}$ sposób precyzyjny i mają wyznaczony dokładny plan wy/załadunków w poszczególnych portach. Port w Gdańsku przyjmuje statki obu serwisów raz w tygodniu, co daje polskim eksporterom możliwość wysyłek ładunków dwa razy w tygodniu, z czasem tranzytu porównywalnym z portami w Hamburgu czy Rotterdamie. Podróż statku na trasie Hamburg/Rotterdam-Szanghaj trwa około 31 dni, a Hamburg/RotterdamSingapur około 28 dni. Polskim eksporterom daje to możliwość konkurowania w planowaniu produkcji i załadunku towarów przeznaczonych na rynki azjatyckie przez cały tydzień. Dodatkowo, eksporterzy eliminują ryzyko opóźnień wynikających z przeładunków w portach Europy Zachodniej. W przypadku wyjść z Gdyni kontenery dostarczane są do niemieckich portów na statkach feederowych i tam przeładowywane na statki oceaniczne serwisów dalekowschodnich. Przed polskimi eksporterami stawia to wyzwania $\mathrm{w}$ postaci zwiększonego popytu na miejsce na statkach oceanicznych w Hamburgu (portu hubu dla wielu europejskich ładunków) oraz opóźnień czy wydłużonego czasu podróży wynikających z niedopasowania połączeń lub kongestii w porcie przeładunkowym.

Przy negocjacjach warunków dostaw usług transportu morskiego na statkach serwisów obsługiwanych w Gdańsku producenci i spedytorzy mają silną pozycję negocjacyjna, ponieważ od ich wolumenów bezpośrednio zależy wypełnienie statków oraz wysokość stawek frachtowych. Daje to również możliwości rozszerzenia współpracy z odbiorcami i przejmowania gestii transportowej lub zmiany na warunki CFR, czyli ",koszt i fracht", ustandarowanych w zbiorze międzynarodowych warunków sprzedaży i zakupu, z których wynikają prawa i obowiązki eksportera i importera w zakresie organizacji transportu, pokrycia jego 
kosztów i ryzyka, odnoszących się do Konwencji ONZ dotyczącej Kontraktów dla Międzynarodowej Sprzedaży Dóbr, powszechnie nazywanymi INCOTERMS 2010.

Polityka frachtowa armatorów kształtowana jest pod wpływem wielu czynników i zdarzeń gospodarczo-politycznych, dlatego ich reakcje na rynku obsługiwanym przez bezpośrednie serwisy kontenerowe są zazwyczaj szybsze i cechują się większą elastycznością. W zależności od siły popytu i podaży mogą oni skutecznie dostosować swoją politykę cenową do swojej kondycji na rynku, co zazwyczaj ma odzwierciedlenie w wysokościach frachtów. Szacuje się, że różnica pomiędzy stawkami frachtowymi z Gdyni i Gdańska do Szanghaju waha się od kilkudziesięciu do kilkuset dolarów per TEU, ponieważ armatorzy, których statki zawijają do Gdyni naliczają opłatę za koszt dowozu kontenera feederem do Hamburga, podnoszącą wysokość całkowitego frachtu, to jest tzw. pre-carriage lub on-carriage feeder fee (można przyjąć, że za 40-stopowy kontener wynosi on około 500 USD). W przypadku kontenerów typu reefer na politykę frachtową armatorów wpływ mają również dostępność sprzętu specjalistycznego oraz wymagany czas podróży (w szczególności dla towarów wrażliwych, drogich i przewożonych $w$ temperaturach dodatnich), dlatego oferty armatorów znacznie różnią się między sobą. Bywa, że polscy producenci korzystają z serwisów, których statki zawijają bezpośrednio do portów zagranicznych i wówczas spedytorzy podejmują kontenery chłodnicze $\mathrm{w}$ portach załadunku, np. Hamburgu. Wiąże się to z wyższym kosztem transportu lądowego, najczęściej drogowego. Dla przykładu, w maju 2018 roku cena za przewóz drogowy kontenera 40’RH z Łodzi do Gdańska, przy podjęciu pustego kontenera z Gdańska, wynosiła około 2500 złotych. Natomiast przewóz z Łódzi do Hamburga, przy podjęciu pustego kontenera w porcie Hamburg, wynosił około 1600 euro, to jest: 6851,68 złotych według średniego kursu euro NBP z dnia 15 maja 2018 roku: 1 EUR = 4,2823 PLN (Narodowy Bank Polski [NPB], 2018).

W transporcie morskim do przewozu towarów spożywczych, a zwłaszcza wrażliwych na zmiany temperatur, armatorzy oferują usługi w kontererach izotermicznych lub chłodniczych. Według danych Drewry Maritime Research w 2016 r. na świecie dostępna była flota o pojemności 2,656 milionów TEU kontenerów chłodniczych, z czego aż 92,6\% kontenerów chłodniczych czterdziestostopowych o wysokości 9 stóp i 6 cali, znanych jako 40ft high-cube reefer, oznaczanych 40’RH. Wymogi techniczne kontenerów określa Komitet Techniczny 104 działający przy Międzynarodowej Organizacji Normalizacyjnej (International Organization for Standardization - ISO), która nie tylko ustandaryzowała parametry w skali światowej, ale dokonała również podziału kontenerów w zależności od rodzaju ładunku, dla którego są przeznaczone. Według klasyfikacji ISO (norma ISO 830:1999, która odświeżana jest co 5 lat) kontener izotermiczny lub chłodniczy jest specjalnym urządzeniem służącym do transportu nielotniczego (Naider, Marciniak-Neider, 1995). Kontenery tego typu umożliwiają przewóz w 
warunkach dostosowanych do wymagań produktów: świeżych owoców, mrożonego mięsa, mrożonych warzyw, słodyczy, produktów mlecznych czy farmaceutyków. Najczęściej spotyka się kontenery chłodnicze, które wyposażone są w agregaty chłodzące, utrzymujące wymaganą temperaturę w przedziale od minus 25 do plus 25 stopni Celsjusza (Kotowska, Mańkowska, Pluciński, 2016). Kontenery chłodnicze posiadają także system wentylacji, umożliwiający wymianę powietrza, by zapobiegać niszczeniu towarów lub przedwczesnemu dojrzewaniu owoców. Wymiana następuje poprzez wpuszczenie do środka kontenera świeżego powietrza z zewnątrz w przedziale od 0 do 285 metrów sześciennych na godzinę. Armatorzy unowocześniają technologię przewozu i urządzenia chłodnicze, umożliwiając nie tylko kontrolę wentylacji i temperatury, ale również wilgotności i atmosfery równocześnie. Kontenery z technologiami kontolowania atmosfery, tzw. CA (control atmosphere) i MA (modified atmosphere) częściej stosowane są na szlakach żeglugowych, gdzie transportuje się np. awokado, wybrane odmiany jabłek, brzoskwinie czy winogrona. W Polsce najczęściej wykorzystuje się kontenery chłodnicze o możliwościach kontroli temperatury, wentylacji i/lub wilgotności.

\subsection{Funkcjonowanie logistycznego chłodniczego łańcucha dostaw}

W przemieszczaniu ładunków wymagających chłodzenia zaangażowanych jest wielu uczestników procesu logistycznego, których celem nadrzędnym jest dostarczenie sprawnej i szybkiej usługi spedycyjno-transportowej. Tworzą oni tzw. chłodniczy logistyczny łańcuch dostaw. Spedytorzy, którzy najczęściej koordynują proces od załadunku do dostawy, starają się zapewnić możliwie najszybszy czas przewozu, ograniczając przy tym ryzyko związane z utratą jakości towarów, szkodami fizycznymi, karami umownymi, brakiem odpowiednich ubezpieczeń, licencji eksportowo-importowych oraz sprawnych odpraw celnofitosanitarnych w portach załadunku i wyładunku.

W całym systemie chłodniczego łańcucha dostaw odcinek transportu morskiego wydaje się najmniej skomplikowany, a rolę armatorów i operatorów portowych można uprościć do kilku zadań w całym procesie logistycznym, tj. zapewnienia sprawnego i czystego pustego kontenera, przyjęcia kontenera do portu przez terminal, przechowania włączonego kontenera i monitoringu w porcie, załadowania na odpowiedni statek i monitoringu, ewentualnie przeładunku zgodnie z planem podróży, dostarczenia kontenera do portu wyładunku i podobnie jak w porcie załadunku, przechowania i monitorowania pracy kontenera do momentu odprawienia i odbioru wysyłki przez importera lub pracującego $\mathrm{w}$ jego imieniu spedytora. Znacznie więcej zadań muszą wykonać eksporterzy, którzy, oprócz produkcji i sprzedaży towarów, odpowiadają również za procesy logistyczne na etapie produkcji opakowań, uzyskiwania certyfikatów jakości, pozwoleń handlowych itp., dlatego sprawność chłodniczego łańcucha dostaw w 
znacznej mierze zależy od planowania i realizacji zadań logistycznych przed załadunkiem na statek.

Część przepisów regulujących transport drogowy w Polsce pomaga $\mathrm{w}$ sprawnym transporcie ładunków wrażliwych, chodzi tu o wyłączenie z okresowego zakazu ruchu pojazdów przewożących artykuły szybko psujące się i artykuły spożywcze. Jednakże praktyka wskazuje na potrzebę dalszych prac nad poprawą procesów logistycznych w zakresie obsługi drogowej ładunków chłodzonych, transportu multimodalnego, obsługi wetenaryjno-celnej, jak również terminalowej.

\section{Polski handel z Chinami}

W 2016 roku całkowita wartość polskiego eksportu żywności wyniosła 20,22 mld euro, taki wynik stanowił ok. 11 procent wartości całkowitego polskiego eksportu, która wyniosła 184,84 mld euro. Należy zaznaczyć, że około 80 procent eksportowanej żywności trafiło na rynek Unii Europejskiej, w tym aż 24 proc. całego eksportu rolno-spożywczego do Niemiec. W 2016 roku polscy eksporterzy wysłali do Chin żywność o wartości $92 \mathrm{mln}$ euro, znacznie więcej żywności o łącznej wartości 1,58 mld euro trafiło do Hong Kongu (GUS, 2017). Polscy producenci wciąż poszukują nowych rynków zbytu, a w 2017 roku polskie towary dotarły do 30 nowych rynków. Za jeden z najbardziej perspektywicznych uważa się Azję Południowo-Wschodnią (Eksport polskiej żywności wzróst 13 proc..., 2018).

Rosnące ujemne saldo w polskim handlu zagranicznym z Chinami oznacza, że współpraca z partnerami azjatyckimi rozwija się w szczególności po stronie importowej, natomiast polscy producenci wciąż słabo wykorzystują szanse ekspansji eksportowej na rynku chińskim. W roku 2015 r. ujemne saldo bilansu płatniczego wynosiło 18,664 mld euro, przy wartości eksportu 1,820 mld euro. W 2016 roku ujemny bilans handlowy z Chinami urósł do wartości 19,880 mld euro, przy wartości eksportu 1,727 mld eur. W 2017 roku polski eksport do Chin wyniósł 2,053 mld euro, osiągając blisko dziewiętnastoprocentowy wzrost względem roku 2016. Jednakże w tym samym czasie chiński eksport do Polski wzrósł o 12 procent do wartości 24,271 mld euro. Ze względu na skalę chińskiego eksportu do Polski w obrocie towarowym nastąpiło zwiększenie deficytu do wartości 22,218 mld euro, czyli o około 12 procent. Polski eksport do Chin stanowi 0,99\% całego polskiego eksportu, podczas gdy import z Chin, drugiego najważniejszego rynku, stanowi aż 11,78\% całości polskiego importu (MPiT na podstawie danych MF i GUS, 2018).

Struktura asortymentowa polskiego eksportu wymaga dywersyfikacji, ponieważ oferta polskich produktów eksportowych jest bardzo ograniczona. Obiecującą niszą, na której polscy eksporterzy mogą znaleźć zbyt dla swoich towarów są rynki produktów spożywczych. Do perspektywicznych asortymentów zaliczane są: brojlery, wołowina, żywność przetworzona, przetwory mleczarskie, 
słodycze (szczególnie czekolada), miód, owoce europejskie (Drelich-Skulska, Bobowski, Jankowiak, Skulski, 2012).

Bogacąca się klasa średnia w Chinach coraz częściej szuka dóbr dobrej, europejskiej jakości i wiele polskich przedsiębiorstw coraz lepiej rozpoznaje gusty Chińczyków, z sukcesem przedzierając się przez gąszcz chińskich przepisów importowych. We wrześniu 2017 roku w systemie chińskiej Generalnej Administracji ds. Nadzoru Jakości, Inspekcji i Kwarantanny (AQSIQ) zarejestrowanych było 451 producentów i 740 eksporterów polskiej żywności (Eksport polskiej żywności do Chin zagrożony?..., 2017). Ciągłe prace polegające na docieraniu do dużych grup konsumentów wymagają nie tylko dobrego wywiadu handlowomarketingowego, ale również sprawnej logistyki, spełnienia wymagań fitosanitarnych oraz przejrzystej kontroli jakości polskich produktów. Certyfikaty wymagane przez służby chińskie podlegają licznym procedurom, a przepisy określające standardy są zawiłe, często niezrozumiałe i mogą okazać się bardzo kosztowne, jeśli towar utknie na granicy Chin lub zostanie porzucony przez importera. Dla wielu eksporterów jest to trudna do pokonania bariera wejścia na lokalny rynek, dlatego wstrzymują się z inwestowaniem własnych zasobów w rozwój sprzedaży w Chinach i najczęściej decydują się na prowadzenie działalności gospodarczej poprzez spółki joint venture z partnerem chińskim.

Rząd Chin, pod wpływem nacisków ze strony eksporterów z Unii Europejskiej i USA, wprowadził dwuletni okres przejściowy: od 1 października 2017 roku do 30 września 2019 roku, zanim wprowadzone zostaną surowe regulacje w sprawie importu żywności do Chin. Jest to ważny czas dla polskich producentów i eksporterów, by docierać do chińskiego rynku i dobrze zapoznać się z lokalnymi procedurami. Bezpośrednie serwisy żeglugowe ułatwiają polskim eksporterom dostęp do tamtejszego rynku, dając im szansę na rozwój eksportu żywności (i nie tylko) na Daleki Wschód.

\section{Szanse na wzrost eksportu wybranych towarów}

Dobrym przykładem produktu, który zyskał uznanie chińskich nabywców jest polskie mleko, które, po wewnętrznych skandalach związanych z chińską produkcją mleka zawierającego malaminę, konsumenci $\mathrm{w}$ Chinach postrzegają jako produkt zagraniczny cieszący się większym zaufaniem z powodu lepszej jakości. Dzięki temu swoją pozycję na chińskim rynku ugruntowały produkty polskich marek: SM Mlekovita, Mlekpol i OSM Łowicz. Marketerzy SM Mlekovita zaskoczyli swoją pomysłowością i mleko z wyższej półki sprzedają w niemieckojęzycznym opakowaniu za cenę 12,5 zł za karton (kojarzone jest z niemiecką jakością) (Molga, 2016). OSM Łowicz również eksportuje coraz większe ilości mleka i „szacuje, że w 2017 r. Chińczycy wypiją aż dziesięć milionów litrów mleka z łowickiej spółdzielni. Oczywiście chodzi o mleko UHT (pasteryzowane)"(Szołdra, 2016). Pojawia się pytanie, czy inne produkty mleczarskie mogą również liczyć na sprzedaż w Chinach. Wydaje się, że Polska, jako ósmy najwięk- 
szy na świecie eksporter sera, ma ku temu możliwości (Drewry Maritime Research, 2017). Dodatkowo, w 2017 roku polskie mleczarnie zdecydowały się na zwiększoną produkcję masła (pod wpłwem zwiększonego zapotrzebowania światowego i w szczególności europejskiego rynku na ten towar). Również $\mathrm{w}$ Chinach konsumenci coraz częściej powracają do spożywania masła. Sprawdzone polskie wyroby maślane mogą okazać się kolejnym polskim hitem eksportowym. Według najnowszych danych ForumMleczarskie.pl, mleczarze mogą być pełni optymizmu, ponieważ chiński import produktów mlecznych wciąż rośnie. „W styczniu 2018 roku Chińczycy kupili 43,8\% nabiału więcej, o wartości o 52,5\% wyższej w porównaniu do stycznia 2017 roku" (ForumMleczarskie.pl, 2018).

Polska, będąc trzecim największym eksporterem i producentem jabłek na świecie (Drewry Maritime Research, 2017), po wprowadzeniu rosyjskiego embarga na polskie owoce i warzywa w sierpniu 2014 roku, została zmuszona do szukania nowych rynków zbytu nie tylko w krajach sąsiadujących, ale też za morzem. Podczas ostatnich trzech sezonów polscy sadownicy rozpoczęli współpracę z partnerami z odległych krajów i z roku na rok uczą się, jak usatysfakcjonować zagranicznych konsumentów. Wysokie oczekiwania polscy sadownicy pokładają w uzyskaniu chińskich pozwoleń importowych, które cechują trudne do spełnienia wymagania fitosanitarne. Polscy eksporterzy otrzymali niezbędne pozwolenia w listopadzie 2016 roku. Po kontrolach urzędników z Chin i zakończeniu procedur formalnych uprawnione do eksportu jabłek zostały 453 sady oraz 135 pakowalni. Pierwszy sezon (2016/2017) dla polskich jabłek w Chinach nie był najlepszy, bowiem udało się wyeksportować zaledwie 300 ton owoców (Katner, 2017). W sezonie 2017/2018 polscy sadownicy wysłali znacznie mniej jabłek do Chin niż w sezonie poprzedzającym. Główną przyczyną niewielkiego eksportu do Chin w 2017 r. było zwiększone zapotrzebowanie rynku europejskiego na polskie jabłka. Wiosną 2017 roku Europa została dotknięta przymrozkami, w związku z czym zarówno Polska, jak i Szwecja, Holandia, Belgia, Niemcy, Włochy, Francja zanotowały znacznie mniejsze zbiory (Mulderij, 2018).

Od 2014 roku prowadzone są kampanie promocyjne, mające na celu przekonanie chińskiego konsumenta do kupna dwukolorowych jabłek z Polski (Polsko-Chińska Izba Przemysłowo-Handlowa, 2017). Aby z sukcesem sprzedać jabłka w Chinach, potrzebne jest polskim sadownikom wsparcie rządu oraz badania nad zabezpieczeniem jabłek $\mathrm{w}$ transporcie morskim poprzez właściwe przygotowanie produktu oraz opracowanie dobrych dla polskich odmian jabłek opakowań. Polskie jabłko, by podbić chiński rynek, musi być w stanie przetrwać około 35-dniowy czas podróży drogą morską zakładając oczywiście połączenie bezpośrednie Gdańsk-Szanghaj. Jabłko w podróży wymaga chłodzenia i wentylacji, a takie warunki zapewniają kontenery chłodnicze. Przygotowane do wielotygodniowej podróży jabłka mogą trafić na półki zagranicznych supermarketów w nienaruszonym stanie. Jednak rolą załadowców jest zastosowanie takiej technologii załadunku, która umożliwi dostarczenie odbiorcom towaru zaprezentowa- 
nego przy załadunku. Niestety, praktyka pokazuje, że podatność transportowa polskich odmian jabłek jest niewysoka, dlatego polskie grupy producenckie oraz służby państwowe czeka praca nad uzyskaniem wysokiej jakości jabłka eksportowego, spełniającego wymagania norm jakości konsumentów spoza Unii Europejskiej.

Populacja Chin to prawie jedna piąta populacji świata. Obecnie Chińczycy konsumują prawie trzy raz tyle mięsa, co w roku 1990. Zasoby rolnicze Chin i dyspozycyjność ziem uprawnych nie zaspokajają potrzeb żywieniowych społeczeństwa. Mimo szybkiego i innowacyjnego rozwoju rolnictwa, Chińczycy są zmuszeni do importu jedzenia oraz tworzenia farm w oparciu o modernizacje nawadniania, rozwój technologii i mechanizacji. Dodatkowo, rząd promuje wśród krajowych przedsiębiorstw i inwestorów kupno ziem uprawnych oraz przedsiębiorstw produkujących żywność za granica, na przykład w USA, Tanzanii, Chile czy na Ukrainie (McMillan, 2018).

Największym na polskim rynku producentem mięsa, specjalizującym się $\mathrm{w}$ produkcji mięsa wieprzowego i drobiowego oraz przetworów mięsnych, jest Animex Foods, który posiada w Polsce aż 10 zakładów mięsnych i zakład pierzarski. Producent ten przoduje $\mathrm{w}$ eksporcie mięsa na rynki zagraniczne, pozostając niekwestionowanym liderem w swojej branży. Od 1999 roku Animex Foodsynależy do Smithfield Foods Incorporated, inwestora, którego wiedza i doświadczenie na światowym rynku mięsa umożliwiła polskiemu producentowi ekspansję na rynki zagraniczne. W 2013 roku Smithfield Foods, a tym samym także Animex Foods, zostały częścią korporacji, będącej największym producentem mięsa wieprzowego na świecie, WH Group, notowanej na giełdzie w Hong Kongu od 2014 roku z siedzibą główną w mieście Luohe (prowincja Hanan, Chiny). W 2017 roku spółka Smithfields Foods przejęła od grupy Pini dwa zakłady przetwórstwa mięsa oraz projekt inwestycyjny Royal Chicken. W ten sposób Animex zwiększył swoje moce produkcyjne i w najbliższych latach będzie mógł zwiększać sprzedaż eksportową, odpowiadając na rosnący popyt konsumentów zagranicznych (Animex Foods, 2018).

W Polsce około 100 dużych i średnich przedsiębiorstw z branży mięsnej należy do Związku „Polskie Mięso”, z którego w roku 2006 utworzono Izbę Gospodarczą Polskie Mięso. Łączny udział przedsiębiorstw stowarzyszonych w związku w krajowym rynku mięsa i przetworów przekracza $70 \%$, natomiast $\mathrm{w}$ eksporcie 80\% (Polskie Mięso, 2018). Zrzeszenie prowadzi liczne działania mające na celu tworzenie warunków rozwoju branży mięsnej. Przedsiębiorstwa uzyskują wsparcie $\mathrm{w}$ podejmowaniu inicjatyw gospodarczych oraz pomoc marketingowa w prowadzeniu działalności gospodarczej w Polsce i na świecie. Taka współpraca korzystnie wpływa na wizerunek polskich produktów za granicą oraz funkcjonowanie polskich producentów w trudnych warunkach światowej konkurencji. Dla polskiego eksportu mięsa ważny jest nie tylko wizerunek i jakość produktów, ale również sprawność w dostosowaniu się do zmian. Dzięki wymianie informa- 
cji i współpracy producenci działający w związku zapewniają sobie większą odporność na zminy koniunktury, takie jak na przykład: wybuch afrykańskiego pomoru świń (ASF) czy ogólnoeuropejski skandal z konina, o których informacje obiegły cały świat.

\section{Podsumowanie}

Podsumowując dotychczasowe rozważania, można stwierdzić, że aktualna organizacja żeglugi kontenerowej w Gdańsku zachęca polskich producentów do poszerzania swojej działalności i oferty sprzedażowej na rynkach azjatyckich. Połączenia oceaniczne z Gdańska do największych portów na Dalekim Wschodzie dają polskim eksporterom dostęp do największego na świecie rynku konsumentów. Polscy przedsiębiorcy mają możliwość wykorzystania połączeń z Gdańska do budowania relacji $\mathrm{z}$ odbiorcami $\mathrm{w}$ Azji. Bezpośrednie zawinięcia największych na świecie kontenerowców do Gdańska (w ramach dwóch globalnych sojuszy armatorskich) pozwalają polskim przedsiębiorstwom uzyskać przewagę nad konkurentami z regionu Morza Bałtyckiego. Trafne rozpoznanie oczekiwań konsumentów, dobra jakość polskich produktów oraz atrakcyjność aktualnych rozwiązań żeglugi kontenerowej w Gdańsku, pozytywnie wpływają na rozwój polskiego eksportu do krajów azjatyckich. W 2017 roku odnotowano widoczny wzrost polskiego eksportu do Chin $(19 \%)$ oraz rekordowe osiągnięcia portu Gdańsk, gdzie przeładowano 1580505 TEU, przewyższając rezultat z 2016 roku o 22\% (Dziennik Bałtycki, 2018). Współpraca z azjatyckimi partnerami przez Gdańsk korzystnie wpływa na budowę bardziej zrównoważonej wymiany handlowej pomiędzy Polską a Chinami. Jednakże niezbędne są dalsze prace nad ekspansją polskich produktów spożywczych na rynkach azjatyckich, silna promocja oraz badania nad przygotowaniem produktów, szczególnie świeżych, do podróży drogą morską aby móc w pełni wykorzystać potencjał aktualnych rozwiązań żeglugi kontenerowej oraz portu w Gdańsku.

\section{Bibliografia}

1. Ambasada Rzeczypospolitej Polskiej w Pekinie (2017), Wymiana handlowa i aktywność inwestycyjna, Pobrane maj 30, 2018, z http://pekin.msz.gov.pl/pl/wspolpraca_dwustronna/wspolpracagospodarcza/wymi anahandlowa/?printMode=true.

2. Animex Foods (2018), Pobrane maj 20, 2018, z http://www.animex.pl/animex/ofirmie/.

3. Central Inteligence Agency United States Of America (2018), The World Factbook, Pobrane maj 8, 2017, z https://www.cia.gov/library/publications/the-worldfactbook/geos/ch.html.

4. Drelich-Skulska, B., Bobowski, S., Jankowiak, A., Skulski, P. (2012), Nisze rynkowe dla polskich produktów w Chinach, Pobrane maj 15, 2017, z http://www.gochina.gov.pl/files/?id_plik=133. 
5. Drewry Maritime Research (2017), Reefer Shipping Market Review and Forecast Annual Reaport 2017/18, London.

6. Dziennik Bałtycki (2018), Port Gdańsk z historycznym rekordem za 2017 rok. Przeładowano ponad 40 milionów ton towaru, Pobrano wrzesień 1, 2018, z https://dziennikbaltycki.pl/port-gdansk-z-historycznym-rekordem-za-2017-rokprzeladowano-ponad-40-milionow-ton-towaru-zdjecia/ar/12831504.

7. ForumMleczarskie.pl (2018), Pobrane luty 28, 2018 z https://www.forummleczarskie.pl/NEWS/06415/.

8. Główny Urząd Statystyczny (2017), Rocznik Statystyczny Handlu Zagranicznego. Warszawa.

9. Katner, W. (2017), Eksport polskich jabłek do Chin: 100 tysięcy ton w 2022?, Pobrane styczeń 18, 2017, z https://www.agrofakt.pl/eksport-polskich-jablek-do-chin-2022/.

10. Kotowska, I., Mańkowska, M., Pluciński, M. (2016), Morsko-lądowe łańcuchy transportowe. Warszawa: Wydawnictwo Difin SA.

11. McMillan, T. (2018), Nakarmić Chiny. Rosnacy apetyt tego narodu przeobraża chińskie rolnictwo i światowe też, (54-75), Luty 2018, National Geographic Polska.

12. Ministerstwo Przedsiębiorczości i Technologii (2018), Departament Analiz Gospodarczych, syntetyczna informacja o eksporcie i imporcie Polski, styczeń - grudzień 2017 ro$k u \quad w \quad m l n$ EUR, Pobrane sierpień 31, 2018, z https://www.mpit.gov.pl/media/60831/HZ_Syntetyczna_Informacja_styczen_grudzi en_2017ost.pdf.

13. Molga,T. (2016), Mlekovita i jej mleko wskoczyła na najwyższa półkę w chińskim markecie. Ale... udaje niemiecka firmę, Pobrane styczeń 30, 2017, z http://natemat.pl/191395,mlekovita-i-jej-mleko-wskoczyla-na-najwyzsza-polke-wchinskim-markecie-ale-udaje-niemiecka-firme.

14. Mulderij, R. (2018), Overview global apple market, Pobrane czerwiec 15, 2018, z http://www.freshplaza.com/article/189682/OVERVIEW-GLOBAL-APPLE-

MAR-

KET?lipi=urn\%3Ali\%3Apage\%3Ad_flagship3_feed\%3BxDRLm5XPS\%2F2N5s8MRg mDnw\%3D\%3D.

15. Neider, J., Marciniak-Neider, D. (1995), Przewozy intermodalne w handlu międzynarodowym. Warszawa: Polskie Wydawnictwo Ekonomiczne.

16. Newseria.pl (2018), Eksport polskiej żywności wzrósł 13 proc. w ciągu jedenastu miesięcy $2017 \quad$ r., Pobrane kwiecień 18, 2018, z http://www.sadyogrody.pl/handel_i_dystrybucja/106/eksport_polskiej_zywnosci_w zrosl_13_proc_w_ciagu_jedenastu_miesiecy_2017_r_wideo,12738.html.

17. POLSKIE MIĘSO (2018), Pobrane sierpień 25, 2018, z http://polskie-mieso.pl/ozwiazku/.

18. POLSKO-CHIŃSKA IZBA PRZEMYSŁOWO-HANDLOWA (2017), Polskie jabłka w Chinach, Pobrane kwiecień 16, 2018, z http://www.pchiph.org/content/polskiejab\%C5\%82ka-w-chinach.

19. Puls Biznesu (2018), Zarudzki: w 2017 r. eksport żywności wzrósł o 12 proc., Pobrane sierpień 25, 2018, z https://www.pb.pl/zarudzki-w-2017-r-eksport-zywnosci-wzroslo-12-proc-908048. 
20. PortalMorski.pl (2009), Bałtycki hub kontenerowy w Gdańsku?, Pobrane styczeń 18, 2017, z http://www.portalmorski.pl/porty-logistyka/13647-baltycki-hubkontenerowy-w-gdansku,.

21. Reefer Shipping Market Review and Forecast, Annual Report 2016/17, Drewry Maritime Research.

22. Szołdra, J., (2016) Polskie mleko na chińskich pótkach, Pobrane sierpień 21, 2017, z http://jagiellonski24.pl/2016/06/08/polskie-mleko-na-chinskich-polkach.

23. WH Group (2018), Pobrane maj 20, 2018, z http://www.whgroup.com/en/about/profile.php.

24. World Maritime News (2015), Pobrane wrzesień 15, 2018, z https://worldmaritimenews.com/archives/149314/2m-alliance-officially-launched/

25. World Maritime News (2017), Drewry: New Alliance Networks-Winners and Losers, Pobrane

kwiecień

8 , 2018,

http://worldmaritimenews.com/archives/214907/drewry-new-alliance-networkswinners-and-losers/.

\title{
DIRECT DEEP SEA CONTAINER SERVICES FROM GDANSK TO THE FAR EAST AS THE CHANCE FOR DEVELOPMENT OF POLISH FOOD- STUFFS EXPORTS
}

\begin{abstract}
Summary
The article deals with the problem of container shipping, refrigeration supply chain and Polish-Asian trade.

The aim of the study is to indicate the opportunities for the export of Polish food products using the seabourne shipping from Gdańsk. The article analyzes the shipping services from Poland to the Far East and Polish exports of selected agri-food products. The basic concepts and processes of the sea transport have been defined with the focus on the carriage of refrigerated cargo. The need for research and development works to improve the exports of foodstuffs from Poland was indicated.

Key words: export, shipping alliances, refrigerated containers, container
\end{abstract}


